\title{
Deficit in Propriety? Cooperative Learning and Group Self-evaluation in Higher Education
}

\author{
Rasa Nedzinskaitè-Mačiūniené $\dot{1}^{1}$, Inga Minelgaite ${ }^{2}$, Sigurdur Gudjonsson ${ }^{3}$ \\ Vytautas Magnus University, K. Donelaičio g. 58, LT-44248, Kaunas, Lithuania, rasa.nedzinskaite-maciuniene@vdu.lt \\ University of Iceland, School of Business, Gimli v. Saemundargata, 101 Reykjavik, Iceland, inm@hi.is \\ University of Iceland, School of Business, Gimli v. Saemundargata, 101 Reykjavik, Iceland, siggig@hi.is
}

\begin{abstract}
The aim of the article is to unveil how the application of the collaborative learning strategy in higher education (HE) setting combines self-assessment of group activities with peer-to-group and teacher evaluation. The results reveal that the groups' self-evaluation is considerably more positively than evaluation by the teacher or peers. The antecedents of these results are likely embedded in 1) the cultural context with dominant individual values; 2) impact of business study as discipline, and: 3 ) challenges in implementing a collaborative learning strategy in the HE sector.
\end{abstract}

Keywords: higher education, cooperative learning, group self-evaluation, peer group evaluation.

\section{Introduction}

In today's job market, there is a need for specific skills to solve non-routine tasks. The greater priority refers to competencies such as complex problem solving, critical thinking, creativity, people management, emotional intelligence, leadership, decision-making, negotiation, cognitive flexibility, etc. (World Economic Forum, 2016). Most of these competencies relate to the human ability to collaborate and cooperate. In addition, in a changing society, the social systems of personal interaction are also changing. This is a shift from competition and individualism to collaboration (Gilies \& Ashman, 2003). In order to accommodate this transition, there is a need for an integrated cooperative 
teaching approach in higher education. Cooperative learning is a strategy that has been widely used in a K-12 school and maintains its relevance (Okpala \& Okpala, 2014). There is a wealth of research that substantiates the positive impact of cooperative learning strategies on learning outcomes (Scager et al., 2016; Johnson et al., 2007), such as higher self-esteem, acquisition of collaborative skills, demonstration of task-related behaviors, engagement in the educational process, and so forth (Bennett et al., 1991).

The results of the OECD PISA 2015 (2017) study show that students' collaborative problem-solving ability is positively related to performance in the core PISA subjects (science, reading, and mathematics). The largest share of such students is in the economically strongest countries (e.g. USA, UK, New Zealand, Australia, etc.). However, there are still limited research studies on how a cooperative learning strategy works with adults, especially in higher education settings. More specifically, there is a lack of research analyzing how the application of this teaching strategy in higher education is related to adequate student self-assessment. The study by Minelgaite et al. (2019) found that more than $87 \%$ of business students overrate their own work. Recent research (Minelgaite et al., 2019) has also shown that self-assessment skills are not developed in school; therefore its application is a challenge in higher education settings. Based on these factors, our research question is: how do groups evaluate themselves in comparison to peer and teacher evaluation in higher education? As suggested by the literature, economics, and business students are more self-interested than students in other disciplines, a feature contributing to the selection of the particular population in this research (Minelgaite et al., 2019; Klein et al., 2007). Therefore, in this article on cooperative learning, the focus is on group work, self- and peer- evaluation in higher education using a cooperative teaching approach.

\section{Literature Review}

\section{Elements of cooperative learning}

Not all group work can be classed as cooperative learning. The literature suggests that a cooperative learning strategy has a few distinct features which separate cooperative learning from simple groupwork (Bennett et al., 1991; Johnson et al., 2007). The differentiating features of cooperative learning are positive interdependence, individual accountability, face-to-face interaction, social skills, and processing (Bennett et al., 1991; Johnson et al., 2007). Positive interdependence implies that all members of the group feel connected with each other while achieving a common goal. For a group to succeed, each of its members must succeed. In this context, the term of individual accountability emerges and is defined as the responsibility of each group member for what they learn. Another element, face-to-face interaction, suggests close proximity and communication of group members, which contributes to advancing progress in group work. Group 
effectiveness requires interaction with other skills that help to exchange information, resolve, and manage conflicts, so-called social skills. Finally, processing, yet another element of cooperative learning, is aimed at team members evaluating their collaborative efforts and deciding on what should be improved. Although more than a decade has passed since the first conceptual works on cooperative learning, the essential elements that have been singled out remain the same.

Cooperative learning strategy is an active learning strategy (Johnson et al., 2007) and is based on social constructivism learning theory. Embedded in the epistemology of social constructivism, the learner constructs their knowledge by combining new with old knowledge into a common schema. An essential condition in this process is that new knowledge is integrated into schemes only when the learner interacts with other learners (Petty, 2009). There are various models of learner interaction in educational practice found in the literature. In a cooperative teaching approach, learning activities can be organized in three ways: competitive ("I, but not you"), individualistic ("alone, I'm so better"), or cooperative ("both we and I"). According to Johnson and Johnson (1998), cooperative interaction may be contrasted with competitive and individualistic interactions. As early as 1983, a study by Johnson revealed that the cooperative learning model leads to interpersonal learner interaction, which is not evident in other models. In subsequent work, Johnson and Johnson (2003) distinguish the essential components of social interdependence and their differences by analyzing the different interaction models provided in the table below.

Table 1

Comparison of Different Interaction Models

\begin{tabular}{llll}
\hline & \multicolumn{1}{c}{ Competitive } & \multicolumn{1}{c}{ Individualistic } & \multicolumn{1}{c}{ Cooperative } \\
\hline Benefit & Differential & Self & Mutual \\
Efficacy & Differential & Self & Joint \\
Motivation & Extrinsic & Extrinsic & Intrinsic \\
Meta-learning & Defensive adherence & No intellectual & Epistemic curiosity \\
& aroused by opposing & challenge & $\begin{array}{l}\text { aroused by opposing } \\
\text { views }\end{array}$ \\
& views & Low & High \\
\hline
\end{tabular}

Source: Johnson, D. W., and Johnson, R. T. (2003). Student motivation in co-operative groups: Social interdependence theory. In R. M. Gilies and A. F. Ashman (Eds.), Co-operative Learning: The social and intellectual outcomes of learning in groups. London and New York: Routledge Falmer, p. 142.

In other words, in cooperative interaction, unlike the other two models, performance is driven by intrinsic motivation, and in this way achieving a common goal, strengthening collective efficacy, and achieving higher commitment. As subsequent studies (Pescosolido, 2003) show, collective efficacy is related to overall group performance and effectiveness. 
Assessment strategies change with different interaction models (Bennett et al., 1991). For example, in the competitive interaction model, normative assessment is applied, where the best-performing student gets the highest grade. This model makes it possible to compare learners with each other. However, in the individualistic and cooperative interactions, the criterion-referenced assessment is applied. Here the learners are assessed against pre-defined criteria and in compliance with these criteria. In cooperative interaction, not only is individual performance assessed, but also overall group performance. Academic and social achievements are valued in a collaborative learning strategy. A key difference in a collaborative learning strategy is that learners are involved in the assessment process. Therefore, in the assessment process, it is important to plan what will be assessed (academic and/or social skills); who will assess (teacher, learner, peer, group or etc.), and how it will be assessed (summative, formative, criterion referenced, etc.). The essential aspects of planning this strategy ought to be considered what assessment scheme will be used, and what will be the balance in the final assessment between teacher and learner assessment. The most common assessment schemes offered by the literature are: self-assessment, teacher evaluation, evaluation of one's own group working on the assignment, and peer evaluation of another group's work. Johnson and Johnson (1999) recognized the necessity to integrate cooperative learning with competitive and individualistic learning. Whichever model of learner interaction will be chosen depends on: 1) the teaching / learning goal;2) the educator's philosophical stance on teaching and learning; 3) pupils / students and the skills they are seeking to acquire; 4) class / group prevailing cultures (individualism or cooperation). Furthermore, the model of interaction determines how students intercommunicate with each other, the teacher, learning materials, and the learning environment.

\section{Cooperative learning in higher education}

The application of a collaborative learning strategy at the K-12 level has been extensively researched and empirically grounded. However, in the higher education system, the application of a collaborative learning strategy has received little attention, even though the relevance of the application of cooperative learning in the higher education system is increasing. As long ago as 1997, Kaufman and colleagues analyzed the subtleties of applying cooperative learning in different study disciplines. Their study revealed that regardless of the study discipline, all students who participated in the research 'reported that this approach enhances their learning, problem-solving, critical thinking, communication skills, and motivation' (p. 61). Recent research on the integration of cooperative learning into higher education also confirms the positive impact of cooperative learning on students' learning outcomes. For example, an empirical study by Okpala and Okpala (2014) contended that cooperative learning is 'a strong pedagogical strategy in the improvement of learning outcomes for adult learners in higher education' (p. 265). Another group of Dutch researchers (Scager et al., 2016), based on five different undergraduate courses in 
the life sciences, argue that the cooperative design of these courses fostered the students' sense of responsibility. Furthermore, there was exhibited a sense of responsibility and shared ownership of both the collaborative process and the product that the group made.

The application of cooperative learning in different disciplines of higher education receives unequal attention and is applied for different purposes. For example, Kimmelmann and Lang (2019) apply cooperative learning in teacher education, attempting to establish closer cooperation between universities and schools. Buchs et al. (2016) applied it in order to improve the learning outcomes of statistics and psychology students. Scager et al. (2016) implemented cooperative learning in life sciences courses, seeking to increase the effectiveness of collaboration in these courses. Meanwhile, Okpala and Okpala (2014) examined the impact of participation in cooperative learning structures in African-American adult education learning outcomes and engagement. Furthermore, Zain et al. (2009) examined the influence of the cooperative learning approach on students' performance and attitude in an economics course.

Within the business education literature, although limited, there are a number of studies that have examined the link between cooperative learning and students' learning outcomes (Hampton\& Grudnitski, 1996; Siciliano, 2001; Attle \& Baker, 2007; Stanley, Zhang, 2020). The body of literature suggests that the cooperative teaching approach has a positive impact on business students' learning performance. For example, the research of Siciliano (2001) showed that inclusion of this teaching strategy into the study process helped 'to keep team members focused on the task during each exercise and to provide motivation for students to assist one another in understanding course concepts and theories' (p. 15). Hampton and Grudnitski (1996) found that a cooperative learning strategy is a useful pedagogical tool for low achievers to succeed. The management and organizational science literature (Siciliano, 2001; Attle \& Baker, 2007) suggests that business in nature includes both - cooperation and competition. Therefore, the question arises regarding how the higher education sector can integrate both these components.

Despite the scientific evidence on the importance of applying cooperative learning in educational practice, this strategy is widely underused in actual educational settings. The growing body of research (Kaufman et al., 1997; Buchs, 2016) argues that cooperative learning implementation in higher education is more complex than integrating into a K-12 setting. Some studies (Kaufman et al., 1997; Millis, 2010) have focused on changes in course design related to cooperative learning and human preparation. In other words, in a cooperative teaching approach, the role of the teacher changes from instructor to facilitator. Planning and implementing a cooperative approach in practice begins with making decisions before the lecture (e.g. determine objectives; group students; prepare material resources), then setting the lecture (e.g. structuring positive interdependence; and individual accountability), monitoring the group work, and evaluating the process of assignment implementation. The above-mentioned practices require new skills and change on the part of the educators. Implementing cooperative learning in higher 
education also requires more material resources than a lecture-based course. Yet another issue when implementing cooperative learning relates to students' learning profiles. It means that this approach of teaching will not be preferred by all students. It is mainly because this teaching method requires students to become actively involved in the educational process, not just remaining in a passive listener's role. Thus, the cooperative learning strategy requires different preparation from both the teacher and the student.

Buchs et al. (2016) note that for the successful application of cooperative learning in higher education, it is important to consider the specifics of the university as an organizational environment. Characteristically the university environment itself is competitive, which is philosophically at odds with the cooperative teaching/learning approach. In this environment, students are competing for their study place (e.g. scholarships) with each other. Another important aspect is that it is difficult to ensure that cooperative learning does not become a single initiative but a teaching approach across a whole study program, since in reality different study subjects pursue different goals.

\section{The Current Study}

Despite the considerable amount of research on collaborative learning, less is known about how the application of this teaching strategy in higher education is related to adequate student self-assessment. Little is also known about the application of this strategy in business schools. Exploring the implementation of cooperative learning in higher education in an Icelandic context is important for several reasons. Firstly, based on Hofstede's societal cultural dimensions model, Iceland is a highly individualistic society (Aðalsteinsson et al., 2011; Mixa \& Vaiman, 2015). Entrepreneurship and innovation are strongly embedded in the culture and there are many shared characteristics in American and Icelandic cultural values (Snaebjornsson et al., 2017). There is materialistic pressure in Iceland, which promotes the social compulsion to compete with others on material things. Looking at the field of education, the individualistic direction of society is also visible. According to the OECD PISA (2017) study, the collaborative problem-solving performance of Icelandic 15-year-olds is below the OECD average. In addition, girls have higher collaborative problem-solving skills than boys. The survey data also revealed that, of all the countries surveyed, the majority of Icelandic students believe that decisions made individually are better than those made in teams. In other words, at the secondary school level, the individualistic orientation of the individual has spread and become entrenched. Consequently, individuals with a value-oriented approach to individualism and competition enter Iceland's higher education system.

Secondly, the business and management field in Iceland somewhat different than in other Nordic countries (Mixa \&Vaiman, 2015). More specifically, Mixa and Vaiman (2015) propose that, in terms of individualism, as defined by Hofstede's dimensions, 
that Icelandic managers are more individualistic than managers in other Nordic countries. Furthermore, it is suggested that when the individualism dimension is considered in management settings, Icelanders are more similar to other nations with the highest scores in the world, such as the United States, the Netherlands, Australia, Sweden, and the United Kingdom. Minelgaite et al. (2017) argue that business culture in Iceland is unique. There are some characteristics supporting that contention, e.g. managers are not afraid of taking risks, are thought to improvise, and are unpredictable, to name a few. Furthermore, communication is flat; decisions are made relatively quickly, including autonomy in decision-making in the lower level of an organization's hierarchy.

The education of future business employees faces the challenge to correspond to the 'real business world'. Therefore, when preparing future specialists, it is crucial to ensure the perspective includes both the business context and the specific values of competition, individualism, and cooperation.

\section{Methodology}

The main research focus of this study was to investigate how do groups evaluate themselves in comparison to group peer and teacher evaluation using a cooperative teaching approach? In order to answer the research questions, the study was conducted at the University of Iceland, Iceland. First year undergraduate students at the University of Iceland studying management were asked to evaluate their group project, to make a peer evaluation of another group's work.

\section{Participants}

During the first year, bachelor students at the School of Business, University of Iceland studying management were asked to evaluate their own work in a group video presentation assignment. The participants in the research all took part in the course, titled "Introduction to Management". Out of the 168 students, 50\% were female and 50\% were male. Participants in this research, while taking the 'Introduction to management' course, between other topics, covered business ethics, stakeholder theory, and aspects of corporate social responsibility. Therefore, the students were exposed to the notion that pure self-interest is not the sole purpose of an organization, nor should it be the only goal of an individual. The learning process was based on a collaborative teaching/learning strategy. The study was carried out during the Spring semester (2019-2020 academic year) and students were tasked to produce a group assignment (video) and then give their peers a grade, as well as to evaluate themselves as a group. The students were informed that they would receive a grade partly dependent on their group self-assessment. 


\section{Course description and group assignment design}

This is one of the most well subscribed courses, as it is compulsory for all business studies (BS) students studying at the bachelor level at the School of Business. The course is titled 'Introduction to Management' and covers a broad range of subjects in management, such as Strategic management. The main objective of the course is that the students gain knowledge and understanding of key management concepts, theories, and tools or methods connected to the manager's job. The focus is on managerial work and human resource management and communication in the workplace. Various teaching and learning methods are utilized.

The above-mentioned course consists of theoretical and practical assignments. A group project was one of the tasks assigned for students and worth $30 \%$ of the final grade. The goal of the group work was to prepare a video presentation (video clip) about an assigned topic on organizational management. Students were randomly assigned into groups of 6 to 7 people. Each group was assigned their topic by the teacher.

The main criterion of this video presentation was an adequate presentation of the topic or content covering the assigned topic, engagement of the audience, and to do so in a creative way. 2 groups presented their video presentation at each lecture. The duration of each presentation was from 5 to 7 minutes. Those presenting groups also needed to prepare 2 questions on the topic to ask the other presenting group. Groups had to send the questions to teachers before $10 \mathrm{pm}$ on the day before a presentation. When both video presentations were completed, all 4 questions (2 from each group) were put on display. The groups had 10 minutes to answer the questions. Each team member then had to write the answer (which he/she received from the other group) on a piece of paper. All students also had to write down the answers to these (4) questions as some of these questions might have appeared in the final exam. After spending 10 minutes answering the questions individually, the groups had 15 minutes to decide upon the groups agreed to answer.

The assessment and evaluation process of the group project aligned with cooperative learning strategy requirements. This meant that the assessment process involved the active participation of the individual student, groups, and their teacher. In total, students derived $30 \%$ of their final grade from this project: $20 \%$ group and $10 \%$ individual. The $20 \%$ grade for the group aspects was comprised as follows: teacher gave $12 \%$; students / audience $5 \%$ (other groups gave a grade for the lecture and came with 10 sentences where arguments were given for the grade.); and the group's self-rating was $3 \%$. The $10 \%$ individual grade was comprised as follows: $5 \%$ (justification, rated by other members of the group); $2 \%$ (self-assessment of justification); and 3\% (individual's answers to 2 questions at the presentation, rated by the teacher). Evaluating group work (20\%), groups, peers, and the teacher had to follow the following assessment criteria:

- How well is the content described? (5\%)

- How well is the information coordinated / analyzed (criticism / analysis)? (5\%)

- How memorable and well explained is the content? (5\%)

- How original and entertaining is the lecture? (5\%) 


\section{Results}

The main result is that there is the use for group self-assessment is limited since all of the student groups gave themselves the highest possible grade of 10.0. This is even higher than the findings of Minelgaite et al. (2019), who evaluated self-grading by students in group work, finding that $87 \%$ of the students evaluated their work as outstanding and believed they deserved the highest grade possible of 10.0.

If we compare peer grading i.e. what the groups received from their peer group members, we find the groups rate their peer groups on average at 8.8 and the grades ranged from 6.4 to 9.7. However, in contrast to the $100 \%$ self-grading of 10.0, they never gave each other the highest possible mark 10.0. Even the lowest graded group, who received 6.4 from their peers, had given themselves a 10.0. The result from group peer evaluation is shown in Figure 1 below.



Figure 1. Grades Given by Group Peer-assessment

It is noteworthy to see that the average grade given by peers and teachers differ. The highest grade the teacher gave was 10.0 and the lowest was 8.3. See Figure 2 below.

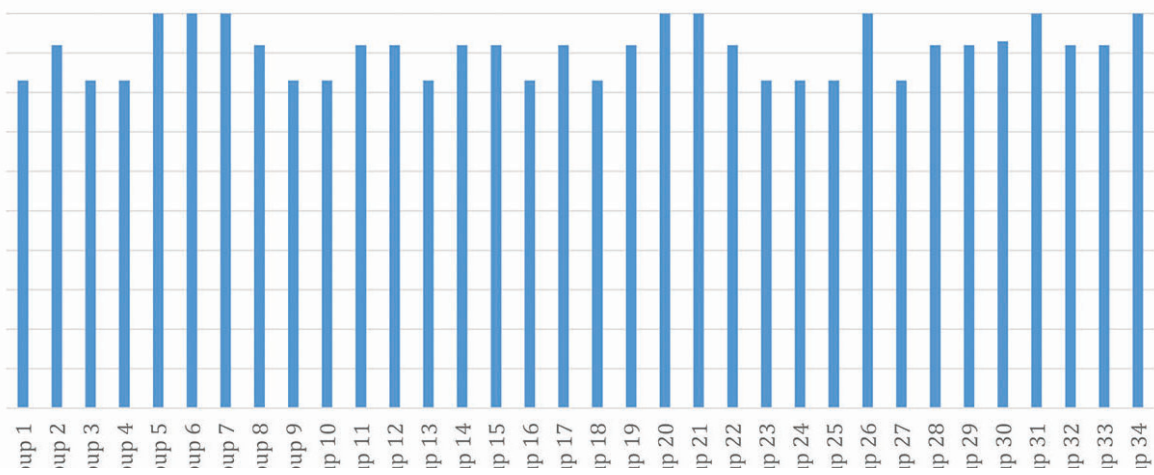

Figure 2. Grades Given by Teachers 
It appears that the students are the hardest judges of their peers, but the softest on themselves. Perhaps this because of their self-interest since it is best for them to get as high a grade as possible. When experiencing competition from their peer, they grade their fellow students lower. In Figure 3 below are the grades the teachers gave the student groups in comparison with group peer evaluation.

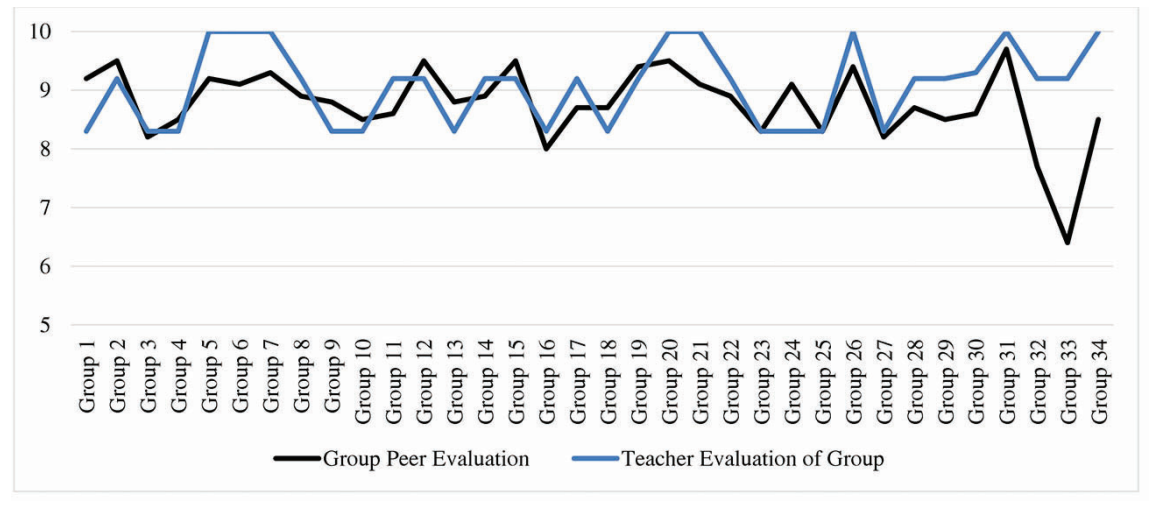

Figure 3. Grades Given by Teachers to the Groups

More in-depth analysis of teachers and peer evaluation of the group assignment present an interesting picture. Even though the majority (61.76 \%) of the groups evaluated their peers' work more critically than the teacher, part of the students' evaluation was more positive. Peer evaluation and teacher evaluation of group 23 and group 25 coincided. It is also noteworthy that the difference between teacher and peer evaluation was 2.8 points when evaluating group 33 , the most among the 34 groups.

Finally, we can see in Figure 4 below the differences in grades groups received from themselves, each other (peer) and the teachers. A statistical analysis is also provided in table 2 below

Table 2

Statistical Analysis

\begin{tabular}{lccc}
\hline & Mean & Median & Standard Deviation \\
\hline Group Self Evaluation & 10 & 10 & 0 \\
Group Peer Evaluation & 8.75 & 8.80 & 0.64 \\
Teacher Evaluation of Group & 9.05 & 9.2 & 0.66 \\
\hline
\end{tabular}




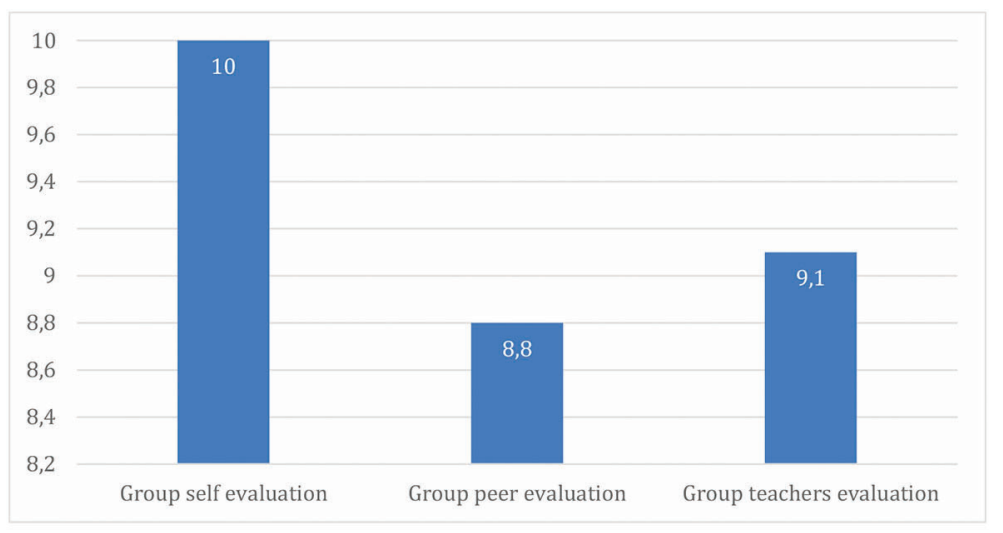

Figure 4. Individual Group Self-evaluation, Teacher and Peer Group-evaluation

It is noteworthy to see that the average grade, student groups received from their assignment valued by their teachers is 9.1. This is much lower than their mean self-assessment grade of 10.0, yet higher than the peer group grade of 8.8 . Students in groups rate themselves much higher than the teachers and peers. The use of self-group assessment is therefore misleading at best. Therefore, it is crucial in the education process to apply learning by collaboration strategy and a 360-degrees evaluation system. In other words, it is important to include learners in the assessment and evaluation process, applying different assessment types (e.g. normative, summative, criterion-based, etc.).

\section{Discussion and Implications for Future Research}

The presented study aimed to provide answers regarding how a group's self-evaluation can be contextualized in and compared to peer-evaluation and teacher evaluation, when educating business students in a higher education setting. The results of the research raise certain questions for discussion. Here we elaborate on a few of them.

Our research indicated that students in groups rate their group work much higher than their teachers and peer groups. This occurred even though all groups followed the same evaluation criteria, which was provided to them in advance of the assessment. As shown in our previous study (Minelgaite et al., 2019) with the same students, 'more than $87 \%$ of students evaluated their own work, individually and in groups, with the highest possible grade' (p. 56). The results of this study imply that individual's self-esteem does not change when working in groups. Conversely, group self-assessment is no more objective or adequate than individual self-assessment of one's work. Furthermore, the results of our research also revealed that when one group evaluated another, as many as $61.76 \%$ of the groups evaluated the work of colleagues more critically than the teacher. We speculate 
that such results emerge from the following contextual conditions: 1) individualistic values prevalent in the (cultural) context in which the research was conducted; 2) the business sector is essentially competitive in nature and the value of competition is reflected in business studies; 3) pedagogical issues in cooperative learning strategy (assessment and evaluation dimension).

The study presented in this paper is context specific, as it was conducted at the School of Business, University of Iceland. As already mentioned in the theoretical part of the article, the literature suggests that Iceland is a highly individualistic society (Aðalsteinsson et al, 2011; Mixa \& Vaiman, 2015). The study by Snaebjornsson et al. (2017) concurred regarding the individualistic orientation of Icelandic national culture and extended this individualistic orientation, suggesting the Icelandic business sector is in general inherently individualistic too (priority is given to "I" instead of "we"). The authors note that 'with regard to management, this dimension is particularly important when it comes to motivating people' (p. 9). These findings are closely related to the findings of other scholars about the nature of business in general. A body of literature (e.g. Attle \& Baker, 2007) has demonstrated that the business world is fundamentally competitive or 'competitive in nature'. The results of our study are in line with the OECD PISA (2017) survey, where Icelandic students were found to have high focus on individualistic problem solving. Therefore, it is natural that the training of future business professionals focuses not only on the development of their cooperation skills, but also in developing competence in competitiveness (Attle \& Baker, 2007). Thus, applying a collaborative learning strategy in business education poses several challenges. This strategy requires considerable readiness and competence of both educators and students to act (learn) according to this strategy. This premise might be challenging to establish, as not all business schools have a requirement for their educators to have pedagogical preparation, and instead the focus is on the taught subject where expertise is deemed of highest value. Therefore, it is natural to have a greater focus on practical skills during studies, but not on the search for effective pedagogical tools.

Despite the specificity of business studies and the contextuality of Iceland as a culture and an island, we suggest that integrating a cooperative learning/teaching strategy into business studies in higher education can contribute to educational processes and serve students as well as teachers in their learning/teaching process. We highlight the importance of the socio-cultural context of the country when educating future business professionals and the need to address peculiarities when considering the appropriateness of educational methods, not just the content of the study. Finally, we propose the need for balance when considering the idiosyncrasies of the context of the learner/teacher, including institutional, sector, and country-level context, and the level of engagement in cooperative learning when developing teaching material with competitive and cooperative interaction models. 
This study was conducted with first-year undergraduate business students. It would be valuable to replicate the study with e.g. fourth-year undergraduate students or graduate (master) level students in order to determine whether experience gained when studying in a higher education institution influences students' attitudes towards self-evaluation on an individual and group level. A comparative study of business students and other study lines that are generally individually focused e.g. sport education would be of interest, in order to facilitate more fine-grained insights regarding the manifestation of individualistic orientation. Furthermore, a comparative study with one or more institutions in other Nordic countries would provide valuable information about the cultural profile and manifestation of individualism. Mixa and Vaiman (2015) pointed out that even though Nordic countries "appear on the surface to share similar cultural traits, financial data indicates Icelanders being more risk-oriented" (p. 356). Therefore, a comparative cross-cultural study could provide useful insights and unveil a deeper portrayal of the underlying manifestation of "Nordic cultural profile" in higher education settings in business studies. National cultures are not static phenomena - as suggested by Magala (2015), cultures constantly evolve. Therefore, the research presented in this paper could serve as a benchmark and help to evaluate country and sector level changes over time.

\section{References}

Aðalsteinsson, G. D., Guðmundsdóttir, S., \& Guðlaugsson, P.Ö. (2011). Íslensk pjóðmenning í ljósi menningarvídda Hofstede [Icelandic national culture in the light of Hofstede's cultural dimensions]. http://skemman.is/handle/ 1946/10399

Attle, S., \& Baker, B. (2007). Cooperative learning in a competitive environment: Classroom applications. International Journal of Teaching and Learning in Higher Education, 19(1), 77-83.

Bennet, B., Rolheiser, C., Stevahn, L. (1991). Cooperative learning: Where heart meets mind. Ontario: Professional Development Associates.

Buchs, C., Gilles, I., Antonietti, J., Ph., \& Butera, F. (2016). Why students need to be prepared to cooperate: A cooperative nudge in statistics learning at university. Educational Psychology, 36(5), 956-974. http://dx.doi.org/10.1080/01443410.2015.1075963

Hampton, D. R., \& Grudnitski, G. (1996). Does cooperative learning mean equal learning? Journal of Education for Business, 72(1), 5-7. http://dx.doi.org/10.1080/08832323.1996.10116817

Johnson, D., \&Johnson, R. (1999). Learning together and alone: Cooperative, competitive, and individualistic learning (5th ed). Boston: Allyn and Bacon.

Johnson, D., Johnson, R., \& Smith, K. (2007). The state of cooperative learning in postsecondary and professional setting. Educational Psychology Review, 19, 15-29.

Johnson, R. T. (1983). Effects of cooperative, competitive, and Individualistic learning experiences on Social Development. Exceptional Children, 49(4), 323-329. https://doi. org/10.1177/001440298304900405 
Kaufman, D., Sutow, E., Dunn, K. (1997). Three approaches to cooperative learning in higher education. The Canadian Journal of Higher Education, 27(2), 37-66.

Kimmelmann, N., Lang, J. (2019) Linkage within teacher education: cooperative learning of teachers and student teachers. European Journal of Teacher Education, 42(1), 52-64. http:// dx.doi.org/10.1080/02619768.2018.1547376

Klein, H. A., Levenburg, N. M., McKendall, M., \& Mothersell, W. (2007). Cheating during the college years: How do business school students compare? Journal of Business Ethics, 72(2), 197-206.

Magala, S. (2015). Interdisciplinary research of cultural diversity. In N.Holden, S. Michailova, S. Tietze (Eds.), The Routledge companion to cross-cultural management. London and New York: Routledge. 362-370.

Millis, B. J. (2010). Why faculty should adopt cooperative learning approaches. In B. J. V. Millis, V. Sterling (Eds.), Cooperative learning in higher education-across the disciplines, across the academy (pp. 1-11). Stylus Publishing.

Minelgaite, I., Nedzinskaitė-Mačiūnienė, R., Kristinsson, K., \& Gudjonsson, S. (2019). 'The emperor is naked!': Exposing (in) efficiency of self- assessment and group - assessment in higher education. Pedagogika, 134(2), 45-60. https://doi.org/10.15823/p.2019.134.3

Mixa, M. W., \& Vaiman, V. (2015). Individualistic vikings: Culture, economics and Iceland. Icelandic Review of Politics and Administration, 11(2), 355-374.

OECD. (2017). PISA 2015 Results (Volume V): Collaborative Problem Solving. PISA: OECD Publishing, Paris. https://doi.org/10.1787/9789264285521-en.

Okpala, C. O., \& Okpala, A. O. (2014). Cooperative learning structure: Catalyst for effective learning for adult learners in higher education. Contemporary Issues in Education Research, 7(4), 259-268.

Pescosolido, A. T. (2003). Group efficacy and group effectiveness: The effects of group efficacy over time on group performance and development. Small Group Research, 34(1), 20-42. https:// doi.org/10.1177/1046496402239576

Petty, G. (2009). Teaching today: A practical guide (4th ed.). UK: Nelson Thornes.

Scager, K., Boonstra, J., Peeters, T., Vulperhorst, J., \& Wiegant, F. (2016). Collaborative learning in higher education: Evoking positive interdependence. CBE-Life Sciences Education, 5(69), 1-9. http://dx.doi.org/10.1187/cbe.16-07-0219

Siciliano, J. I. (2001). How to incorporate cooperative learning principles in the classroom: It's more than just putting students in teams. Journal of Management Education, 25(1), 8-20.

Snaebjornsson, I. M., Edvardsson, I. R., \& Littrell, R. F. (2017). Societal culture in Iceland and Lithuania: managerial implications. SAGE Open. 1-15. https://doi.org/10.1177/2158244017704023

Stanley, D., Zhang, Y. J. (2020). Collaborative learning in online business education: evidence from a field experiment, Journal of Education for Business, 1-7. http://dx.doi.org/10.1080/08 832323.2019.1703097 
World Economic Forum. (2016). The future of jobs: Employment, skills and workforce strategy for the fourth industrial revolution. Global Challenge Insight Report. http://www3.weforum.org/ docs/WEF_Future_of_Jobs.pdf

\title{
Objektyvaus î (si)vertinimo stoka? Mokymosi bendradarbiaujant strategijos taikymas aukštajame moksle
}

\author{
Rasa Nedzinskaitè-Mačiūnienè $\dot{1}^{1}$ Inga Minelgaite ${ }^{2}$, Sigurdur Gudjonsson ${ }^{3}$
}

\begin{abstract}
Vytauto Didžiojo universitetas, K. Donelaičio g. 58, 44248, Kaunas, rasa.nedzinskaite-maciuniene@vdu.lt Islandijos universitetas, Vadybos fakultetas, Gimli v. Saemundargata, 101, Reikjavikas, Islandija, inm@hi.is Islandijos universitetas, Vadybos fakultetas, Gimli v. Saemundargata, 101, Reikjavikas, Islandija, siggig@hi.is
\end{abstract}

\section{Santrauka}

Straipsnyje siekiama atskleisti, kaip taikant mokymosi bendradarbiaujant strategiją aukštajame moksle tarpusavyje dera grupės veiklos įsivertinimas su grupių tarpusavio ir dėstytojo Ł̇vertinimu. Straipsnyje gilinamasi, kaip pasirinkta vertinimo strategija susijusi su adekvačiu grupių i̇sivertinimu ir kitų grupių darbo įvertinimu. Tyrimas atliktas Islandijos universiteto Verslo fakultete su pirmo kurso studentais $(\mathrm{N}=169)$.

Tyrimas atskleidè, kad grupès savo veiklą ịsivertina daug pozityviau, nei jų veiklą ịvertina dėstytojas ar kitos grupès. Visos grupès atlikdamos vertinimą laikèsi tų pačių, iš anksto žinomų vertinimo kriterijų. Kaip rodo ankstesnis mūsų (Minelgaitė ir kt., 2019) tyrimas su tais pačiais studentais, daugiau nei 87 proc. studentų savo darbą vertina aukščiausiu galimu ịvertinimu. Gauti tyrimo rezultatai kelia pagrịstą prielaidą, kad individualusis savęs pervertinimas nepasikeičia pradejus dirbti grupėse, o atvirkščiai - grupès įsivertinimas nèra realistiškesnis ar adekvatesnis nei individualus savo darbo įsivertinimas. Kita vertus, mūsų tyrimo rezultatai taip pat atskleidè, kad, vienoms grupėms vertinant kitas, net 61,76 proc. grupių kolegų darbą vertino kritiškiau nei dèstytojas. Tokius tyrimo rezultatus linktume grịsti tuo, kad: 1) kontekste, kuriame atliktas tyrimas, t. y. Islandijos universitete, užprogramuotos individualiosios vertybės; 2) verslo sektorius iš esmès yra pagrịstas konkurencija; 3) nemenki iššūkiai taikant mokymosi bendradarbiaujant strategiją aukštojo mokslo sektoriuje.

Esminiai žodžiai: aukštasis mokslas, mokymasis bendradarbiaujant, grupès įsivertinimas, grupiu tarpusavio įvertinimas.

Gauta 20200718 / Received 18072020

Priimta 20200930 / Accepted 30092020 